\title{
The Gender Pension Gap in Germany*
}

\author{
Prof. Dr. Alexandra Niessen-Ruenzi \\ and \\ Prof. Dr. Christoph Schneider
}

July 2019

\section{Highlights}

- The gender pension gap in Germany amounts on average to $26 \%$.

- It starts to form at the age of 35 years.

- When entering retirement, women need an extra amount of roughly 25,000 Euro in nominal terms if they aim at closing this gap.

- A 40 year old woman would have to save an extra $2.3 \%$ of her annual income to close it, if the interest rate is $5 \%$, if the inflation rate is $1.5 \%$, and if she lives for another 15 years after retirement.

JEL classification codes: J16 ; J32

Keywords: Gender pension gap, gender equality, retirement savings

\footnotetext{
* Contact: Prof. Dr. Alexandra Niessen-Ruenzi, Chair of Corporate Governance, University of Mannheim, L9, 1-2, 68131, Mannheim, niessen@uni-mannheim.de. Prof. Dr. Christoph Schneider, Department of Finance, University of Tilburg, Prof. de Moorplein 521, 5037 DR Tilburg, C.A.R.Schneider@uvt.nl. This study was financially supported by Fidelity. All errors are our own.
} 


\section{Introduction}

In this short study, we quantify the gender pension gap in Germany and examine how much more women would have to save for retirement to close it. The gender pension gap is first computed as an average across all employees and then split up into various age cohorts and occupations.

Based on a broad database on wage income obtained from the Institute of Employment Research $(I A B)$, to which all German businesses have to report, we estimate each employee's statutory pension entitlements and find that the gender pension gap in Germany amounts on average to $26 \%$. While we do not observe a significant gender pension gap for employees below 35 years of age, the gender pension gap gets larger for older age cohorts. We argue that the decision to start a family is the most likely explanation for this pattern. As female labor force participation reduces drastically after giving birth, and never fully recuperates, labor income decreases and so do statutory pension entitlements of women.

The gender pension gap is lower, and sometimes even negative for occupations where salaries are heavily regulated (for example, municipal clerks) and for occupations that are predominantly performed by women (for example, child care workers). It increases for occupations where salaries depend more on employees' negotiation skills.

We also compute how the gender pension gap can be closed, i.e., how much more women would have to save to make sure that they have the same pension payments (supplemented by their savings) than men upon retirement. We find that in most cases, the additional savings amount needed makes only up for a small fraction of women's annual income, ranging between 1-2\% for most age groups and occupations.

\section{Database and definitions}

Employment and wage data at the establishment and individual level are obtained from the Institute of Employment Research (IAB). The IAB is the research organization of the German employment agency, the Bundesagentur für Arbeit (BA). The BA collects worker and employer contributions to unemployment insurance and distributes unemployment benefits.

All German businesses are required to report detailed information on employment and wages to the BA. We use the Linked-Employer-Employee (LIAB Longitudinal Module) data set to get the full employment history of each individual which will then allow us to estimate her entitlement to a pension from Deutsche Rentenversicherung (German Statutory Pension Insurance Scheme).

The data set we use constitutes a representative random sample of all German employees, stratified according to establishment size, industry and federal state. The establishments in the LIAB 
are selected from the IAB Establishment Panel. All employees are employed at least one day in one of the selected establishments. Thus, selection problems and missing information on employment histories are not a major concern. For each individual, the employment biographies including all observations on employment and benefit receipt (according to Book III of the German Social Code), are reported in the LIAB.

Overall, the IAB data includes 1,918,086 unique individuals (working or getting subsidies like "Arbeitslosengeld" or "-hilfe"). The number of unique individuals in our sample with all necessary information available that are used for our estimation is $1,800,185$. The total sample has $1,734,113$ unique establishments across all German counties. Our sample period is from 1993 to 2014. The data on individuals include information on age, gender, education level (10 categories, for example, university degree or vocational training), occupation (144 occupational groups, employment status ( 2 categories: full time and part time), wages, number of days employed, number of days unemployed and number of days employed in a particular establishment. We also use information on benefit receipts for maternity protection and parental leave to identify interruptions of employment due to child bearing.

Results in this study are only based on individuals' statutory pension entitlement. Our calculations do not include individuals' private wealth, savings, or real-estate, which of course contributes to the overall financial situation upon retirement.

Furthermore, our database does not contain pension entitlements of civil servants, judges, soldiers, and pension schemes for professional groups (for example, medical doctors). However, relative to the volume of all pension systems, statutory pension entitlements cover by far the largest fraction of employees (83\%) and retired individuals (81\%) in Germany (Bundesministerium für Arbeit und Soziales (2016)). The fraction of women in this group is $48.5 \%$.

To determine the gender pension gap, we first compute each employee's statutory pension entitlement based on the number of pension points ("Rentenpunkte"), which the individual is entitled to in 2014. From these, we derive the monthly pension that the individual would obtain in retirement based on the current point value of 33.05 Euro ("Rentenwert"). We do not distinguish between East and West Germany as the differences are completely eliminated in the foreseeable future (until 2024).

As common in the literature (see Flory (2011)), the gender pension gap is defined as the percentage difference between the average monthly gross pension of all women and the average monthly gross pension of all men. 
The formula is:

$$
\text { Gender pension gap }=100 \%-\frac{\text { Average monthly gross pension of women }}{\text { Average monthly gross pension of men }}
$$

It is interpreted as follows: The larger the gender pension gap, the lower are monthly gross pension payments of women compared to those of men. As an example, assume that women expect an average monthly pension of 400 Euro, while men expect an average monthly pension of 500 Euro. In this case, the gender pension gap would be $20 \%$. Note, that a negative gender pension gap would indicate that women expect actually larger monthly gross pension payments compared to men.

\section{The gender pension gap in Germany}

To get an estimate of the size of the gender pension gap in Germany and its sensitivity to the type of calculation, we compute several versions of the pension gap that vary in methodology and assumptions, but should still be economically comparable.

First, we look at all employees in the IAB database for which we can estimate statutory pension entitlements. Across age cohorts, the equal weighted average gender pension gap is $25.97 \%$, while the average gender pension gap weighted by the number of observations in each age cohort is $26.05 \%$ (see Table 1 ).

Second, as we do not observe the entire employment history of older employees in the IAB database (it only starts in 1993) we assume that their employment history in early years is the same as the one we observe for younger cohorts of the same age and gender. In our scenario calculations, we additionally match by occupation. The advantage of this approach is that we can more accurately estimate each individual's pension claim, however, our result rests on the assumption that we can impute missing data from comparable employees. Our calculation for this approach yields a gender pension gap of $22.52 \%$ (equal weighted average) and $22.88 \%$ (age weighted average).

Finally, we restrict our observations to the group of "mid-career" professionals, who belong to the age interval of 25 to 49 years. For these individuals, retirement planning and saving is arguably most important; as they should a) have sufficient income to save for retirement, b) have a sufficient amount of time left to start building up retirement wealth. Depending on the calculation approach, the gender pension gap for this group varies between $16.71 \%$ and $17.97 \%$. 


\begin{tabular}{|lcc|}
\hline \multicolumn{1}{|c}{ Table 1: Average gender pension gap in Germany } & $\begin{array}{c}\text { Equal weighted } \\
\text { gender pension } \\
\text { gap }\end{array}$ & $\begin{array}{c}\text { Age weighted } \\
\text { gender pension } \\
\text { gap }\end{array}$ \\
\hline All employees with IAB employment history & $25.97 \%$ & $26.05 \%$ \\
All employees in IAB including imputed values & $22.52 \%$ & $22.88 \%$ \\
Mid careers (age 25-49) with IAB employment history & $17.30 \%$ & $17.97 \%$ \\
Mid careers (age 25-49) including imputed values & $16.71 \%$ & $17.26 \%$ \\
\hline
\end{tabular}

\section{Cross sectional differences in the gender pension gap}

In the next step, we examine cross-sectional differences in the gender pension gap. We focus on different age cohorts and on different occupations to get a better sense of which women are affected most by the pension gap and thus have the largest need to engage in retirement planning and properly save for this period of their lives.

\subsection{Age cohorts}

The following graph shows gross monthly pension payments to men and women for each age group in our sample. The graph is based on all IAB employees including those that do not have their entire employment history recorded by the IAB. For these individuals, we again impute values based on comparable employees in terms of age, gender, and - in case of our scenario calculations- additionally occupation.

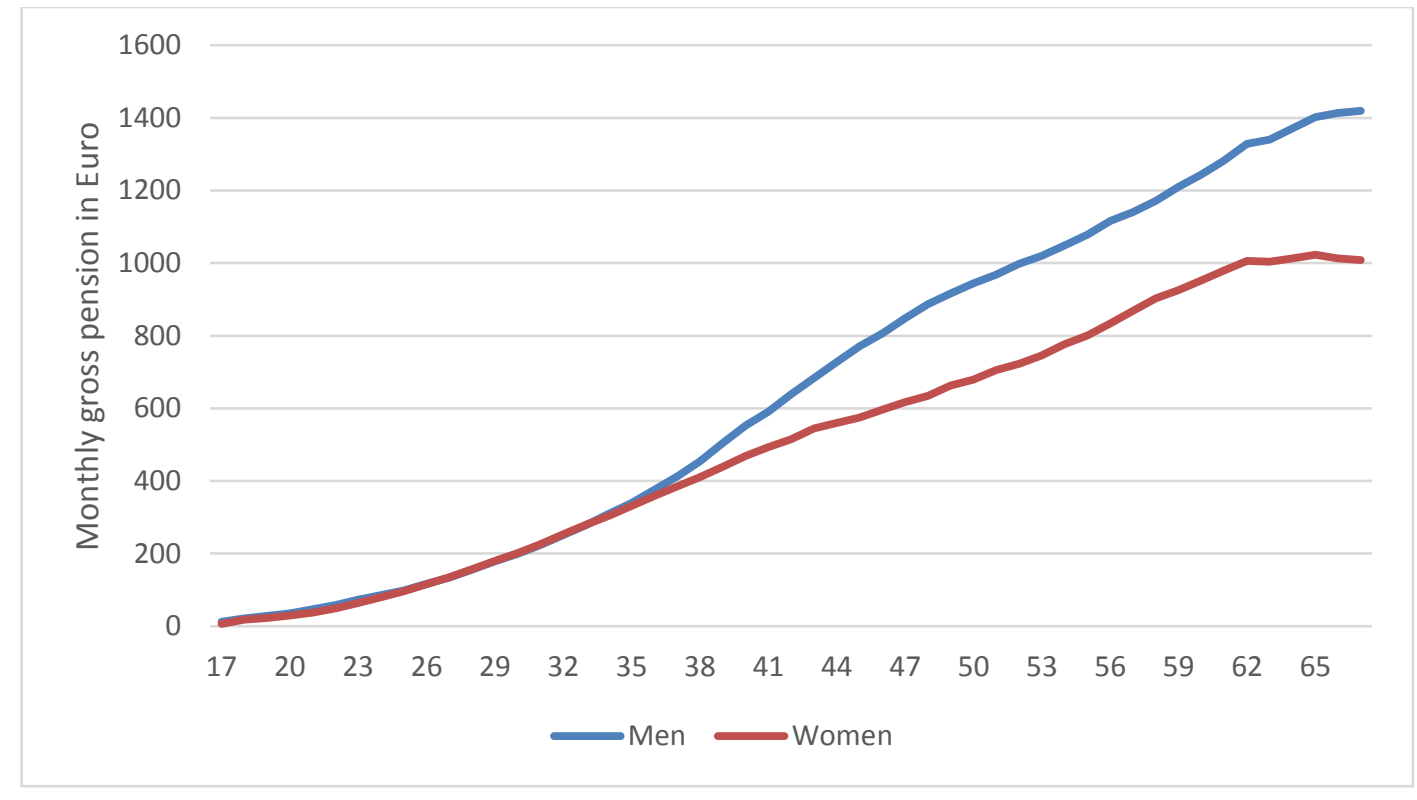

We observe that expected monthly gross pension payments are very similar for both, female and male employees, until the age of 35 . This means that their statutory pension entitlements do not 
differ much in the first years of employment. If they remained on the same wage trajectory, they would receive similar pension payments accordingly. However, starting roughly at the age of 35, men acquire significantly more pension points than women, and thus expect higher gross pension payments upon retirement.

The most likely reason for this pattern is that most people start families in their thirties. Since women are more likely than men to reduce their labor force participation or work only part-time after they gave birth to a child, the gender pay gap starts to develop in this age cohort as well (Chhaochharia, Ghosh, Niessen-Ruenzi, Schneider (2019)). The literature has used the term "motherhood penalty" to describe the drastic changes regarding women's finances and careers after giving birth: They suffer a penalty relative to non-mothers and men in the form of lower perceived competence and commitment, higher professional expectations, lower likelihood of hiring and promotion, and lower recommended salaries (Correll, Benard, Paik (2007)). These changes are likely to contribute to the growth of the gender pension gap in this time period as well.

The following table shows that the gender pension gap is indeed zero for young professionals (2635 years) and then increases to up to $27 \%$ for later age cohorts: ${ }^{1}$

\begin{tabular}{|cc|}
\hline \multicolumn{2}{|c|}{$\begin{array}{c}\text { Table 2: Gender pension gap by age } \\
\text { cohorts }\end{array}$} \\
\hline Age cohort & $\begin{array}{c}\text { Gender pension } \\
\text { gap }\end{array}$ \\
\hline $17-25$ & $17.31 \%$ \\
$26-35$ & $-0.04 \%$ \\
$36-45$ & $15.37 \%$ \\
$46-55$ & $27.06 \%$ \\
$56-67$ & $25.20 \%$ \\
\hline
\end{tabular}

\subsection{Occupations}

We also examine the gender pension gap for various occupations. First, we look at occupations that are quite commonly performed by women on the German labor market. Second, we examine highly ranked occupations that are likely to be populated by female asset amplifiers.

\footnotetext{
${ }^{1}$ The relatively high gender pension gap in the youngest age cohort is in absolute terms actually rather small as the pension claims are just starting to accumulate and indeed women catch up quickly in the mid early twenties. This difference probably stems from the fact that women spend more time in education and start working somewhat later than average man.
} 


\subsubsection{Representative occupations}

\begin{tabular}{|l|c|c|c|}
\hline $\begin{array}{c}\text { Table 3: Gender pension gap for rep- } \\
\text { resentative occupations }\end{array}$ & Age & Children & $\begin{array}{c}\text { Gender } \\
\text { pension gap }\end{array}$ \\
\hline & $(1)$ & $(2)$ & $(3)$ \\
\hline Kindergarten teacher & 42 & no & $12.85 \%$ \\
\hline Insurance agent & 31 & no & $-10.23 \%$ \\
\hline Sales person & 43 & yes & $20.63 \%$ \\
\hline Office clerk & 39 & no & $13.84 \%$ \\
\hline
\end{tabular}

We examine the following representative occupations: Kindergarten teacher (Erzieherin), insurance agent (Versicherungskauffrau), office clerk (Bürokauffrau) and sales person (Verkäuferin). According to the IAB data, a kindergarten teacher aged 42 with no children faces a gender pension gap of $12.85 \%$. In contrast, the gender pension gap is negative for insurance agents aged 31 with no kids, while a female sales person aged 43 with children faces a gender pension gap of $20.63 \%$. A female office clerk with no child faces a gender pension gap of $13.84 \%$ at the age of 39 years.

As an example, these numbers can be interpreted as follows: In nominal terms, a female office clerk needs an extra 10,513 Euro when entering retirement to close this gap, if she lives for another 15 years after entering retirement at the age of $67 .{ }^{2}$ If we assume an annual inflation rate of $1.5 \%$, she will need 15,950 Euro for the same remaining lifetime. ${ }^{3}$ In comparison to the female office clerk, a female sales person with children faces a gender pension gap of $20.63 \%$ at the age of 43. This means that, in nominal terms, she needs an extra 19,792 Euro when entering retirement at the age of 67 to close this gap, if she lives for another 15 years. If we assume an annual inflation rate of $1.5 \%$, she will need 28,293 Euro for the same remaining lifetime.

\subsubsection{Female Asset Amplifiers}

Female asset amplifiers are likely to be well established in their jobs, smart with investments, mid-career professionals, asset and cash rich, and in a position to understand the importance of retirement planning and saving. In the following, we examine various examples for these occupations: Journalist, municipal clerk (Verwaltungsfachangestellte), consultant (Unternehmensberaterin), engineer (Ingenieurin), doctor (Ärztin).

Women working in these jobs are likely to face even larger gender pension gaps, as their salaries are less likely to be regulated and at least part of their salary depends on their negotiation skills. Since women are generally less willing to negotiate for higher salaries (Bertrand (2011)), women

${ }^{2}$ According to the Federal Statistical Office, average life-expectancy in Germany is about 80 years.

${ }^{3}$ According to the Federal Statistical Office, the current inflation rate in Germany varies between 1.3 and 2.3\%. 
in highly ranked occupations usually earn less than men in comparable positions, and as a result, should have lower pension entitlements as well. Furthermore, many higher-paying occupations (such as for example consultancy) involve long working hours and inflexible schedules that are harder to combine with family life (Bertrand (2017)). Thus, women in these occupations may be more likely to reduce working hours drastically after giving birth, which would in turn increase the gender pension gap. We obtain the following results:

\begin{tabular}{|l|c|c|c|}
\hline $\begin{array}{c}\text { Table 4: Gender pension gap for } \\
\text { highly ranked occupations }\end{array}$ & Age & $\begin{array}{c}\text { Number } \\
\text { of } \\
\text { children }\end{array}$ & $\begin{array}{c}\text { Gender } \\
\text { pension } \\
\text { gap }\end{array}$ \\
\hline & $(1)$ & $(2)$ & $(3)$ \\
\hline Journalist & 32 & no & $14.70 \%$ \\
\hline Municipal clerk & 42 & yes & $-5.05 \%$ \\
\hline Consultant & 46 & yes & $25.67 \%$ \\
\hline Engineer & 28 & no & $2.62 \%$ \\
\hline Doctor & 38 & no & $11.60 \%$ \\
\hline
\end{tabular}

Gender pension gaps range from $25.67 \%$ for consultants to $-5.05 \%$ for municipal clerks. This result is in line with the view that occupations with more regulated compensation schemes are less affected by a gender pension gap: A female municipal clerk aged 42 with children faces an even negative gender pension gap, while a female consultant aged 46 with children faces a gender pension gap of $25.67 \%$.

As an example, numbers in the table can be interpreted as follows: A female consultant with children needs, in nominal terms, an extra 44,674 Euro when entering retirement at the age of 67 to close this gap, if she lives for another 15 years. If we assume an annual inflation rate of $1.5 \%$, she will need 61,072 Euro for the same remaining lifetime.

A female doctor with no child faces a gender pension gap of $11.60 \%$ at the age of 38 . In nominal terms, she needs an extra 11,119 Euro when entering retirement to close this gap, if she lives for another 15 years. If we assume an annual inflation rate of 1.5\%, she will need 17,123 Euro for the same remaining lifetime.

\section{How can the gender pension gap be closed?}

One explanation for the gender pension gap is that female employees in Germany earn significantly less than male employees. According to findings from the Federal Statistical Office, for 2018 , there is an average gender pay gap of $21 \%$ in Germany. As individual income is a driving force of statutory pension entitlements, this pay gap translates to a pension gap of similar size.

Closing the gender pension gap requires women to save more for retirement than men. According to the Federal Statistical Office, average life-expectancy in Germany is 83.18 years for women 
born between 2015 and 2017. For men, average life-expectancy is only 78.36 years. In the following, we assume that employees enter retirement at the age of 67 and that they have on average 15 more years to live. Given a gender pension gap of 26\% (see Table 1), when entering retirement, women need an extra amount of 25,179.49 Euro in nominal terms if they aim to close this gap. ${ }^{4}$ If we assume an annual inflation rate of $1.5 \%$ and that the average women has 25 years left until retirement, the extra amount needed is 36,534.07 Euro.

How much money does a female employee have to save during employment if she wants to close the gender pension gap? The answer depends on two important factors.

First, it depends on how much time a woman has left to save money for retirement. Female employees who start saving early on in their employment history need to save less than those who start rather late. The reason is not only that they have more time to save money, but that they benefit also from compound interest.

Second, the necessary saving amount depends on the expected return on her investment. In this regard, it is important to note that women are more risk averse than men. For example, studying the defined contribution pension allocation decision among employees in the US, Bajtelsmit and VanDerhei (1997) find that women invest a relatively greater share in low-risk assets Similarly, both Jianakoplos and Bernasek (1998) and Sunden and Surette (1998) find that women typically invest more risk averse.

In the following Table 5, we calculate for various age cohorts, how much the average female employee in a given age cohort would have to save more each month if she wants to close a gender pension gap of $26 \%$ and lives for another 15 years after retirement. Number are adjusted for inflation and assume an annual inflation rate of $1.5 \%$. In our calculations, we assume two different levels of interest rates, $3 \%$ and $5 \%$. According to the BVI yearbook 2018 obtained from the website of the Bundesverband Investment and Asset Management (BVI), balanced funds delivered an average annual return of $3 \%$ in the time period of 2000-2016. The BVI also reports that in 2019, a global equity fund delivered an average annual return of about $5 \%$. To accommodate different levels of risk appetite among female investors, we perform our calculations for an annual return of $3 \%$ and $5 \%$, respectively.

\footnotetext{
${ }^{4}$ The average female employee needs an extra amount of 16,786.33 Euro upon retirement, if she lives for another 10 years. If she lives for another 20 years, she needs an extra amount of 33,572.66 Euro. In all calculations, we assume for simplicity that no further investments are made upon retirement and that the above mentioned amount of money is equally distributed across months until death.
} 


\begin{tabular}{|c|c|c|c|c|}
\hline \multirow{2}{*}{$\begin{array}{l}\text { Table 5: Savings needed } \\
\text { to close the gender } \\
\text { pension gap } \\
\text { Women's Age }\end{array}$} & \multicolumn{2}{|c|}{$\begin{array}{c}\text { Monthly savings amount } \\
\text { in Euro needed }\end{array}$} & \multicolumn{2}{|c|}{$\begin{array}{l}\text { Fraction of annual } \\
\text { income } \\
\text { that needs to be savec }\end{array}$} \\
\hline & $3 \%$ & $5 \%$ & $3 \%$ & $5 \%$ \\
\hline 17 & 39.16 & 21.10 & $28.4 \%$ & $15.3 \%$ \\
\hline 18 & 40.10 & 21.93 & $10.1 \%$ & $5.5 \%$ \\
\hline 19 & 41.07 & 22.80 & $5.5 \%$ & $3.1 \%$ \\
\hline 20 & 42.08 & 23.72 & $2.7 \%$ & $1.5 \%$ \\
\hline 21 & 43.13 & 24.67 & $2.3 \%$ & $1.3 \%$ \\
\hline 22 & 44.22 & 25.68 & $2.2 \%$ & $1.3 \%$ \\
\hline 23 & 45.37 & 26.73 & $2.1 \%$ & $1.2 \%$ \\
\hline 24 & 46.56 & 27.83 & $2.1 \%$ & $1.2 \%$ \\
\hline 25 & 47.81 & 29.00 & $2.0 \%$ & $1.2 \%$ \\
\hline 26 & 49.11 & 30.22 & $2.0 \%$ & $1.2 \%$ \\
\hline 27 & 50.48 & 31.51 & $2.0 \%$ & $1.3 \%$ \\
\hline 28 & 51.92 & 32.87 & $2.0 \%$ & $1.3 \%$ \\
\hline 29 & 53.42 & 34.30 & $2.0 \%$ & $1.3 \%$ \\
\hline 30 & 55.01 & 35.82 & $2.1 \%$ & $1.4 \%$ \\
\hline 31 & 56.68 & 37.42 & $2.1 \%$ & $1.4 \%$ \\
\hline 32 & 58.44 & 39.12 & $2.2 \%$ & $1.5 \%$ \\
\hline 33 & 60.30 & 40.92 & $2.3 \%$ & $1.5 \%$ \\
\hline 34 & 62.27 & 42.84 & $2.4 \%$ & $1.6 \%$ \\
\hline 35 & 64.36 & 44.87 & $2.4 \%$ & $1.7 \%$ \\
\hline 36 & 66.58 & 47.05 & $2.6 \%$ & $1.8 \%$ \\
\hline 37 & 68.94 & 49.37 & $2.7 \%$ & $1.9 \%$ \\
\hline 38 & 71.46 & 51.85 & $2.8 \%$ & $2.0 \%$ \\
\hline 39 & 74.16 & 54.51 & $2.9 \%$ & $2.2 \%$ \\
\hline 40 & 77.05 & 57.37 & $3.1 \%$ & $2.3 \%$ \\
\hline 41 & 80.15 & 60.46 & $3.2 \%$ & $2.4 \%$ \\
\hline 42 & 83.50 & 63.79 & $3.4 \%$ & $2.6 \%$ \\
\hline 43 & 87.13 & 67.40 & $3.4 \%$ & $2.7 \%$ \\
\hline 44 & 91.06 & 71.33 & $3.6 \%$ & $2.8 \%$ \\
\hline 45 & 95.34 & 75.61 & $3.7 \%$ & $3.0 \%$ \\
\hline 46 & 100.03 & 80.31 & $3.9 \%$ & $3.1 \%$ \\
\hline 47 & 105.18 & 85.47 & $4.0 \%$ & $3.3 \%$ \\
\hline 48 & 110.85 & 91.17 & $4.3 \%$ & $3.5 \%$ \\
\hline 49 & 117.16 & 97.51 & $4.4 \%$ & $3.7 \%$ \\
\hline 50 & 124.19 & 104.59 & $4.7 \%$ & $4.0 \%$ \\
\hline 51 & 132.10 & 112.55 & $5.0 \%$ & $4.3 \%$ \\
\hline 52 & 141.05 & 121.57 & $5.5 \%$ & $4.7 \%$ \\
\hline 53 & 151.27 & 131.88 & $5.9 \%$ & $5.1 \%$ \\
\hline 54 & 163.04 & 143.76 & $6.4 \%$ & $5.6 \%$ \\
\hline 55 & 176.77 & 157.61 & $7.0 \%$ & $6.2 \%$ \\
\hline 56 & 192.98 & 173.98 & $7.6 \%$ & $6.8 \%$ \\
\hline 57 & 212.42 & 193.61 & $8.4 \%$ & $7.7 \%$ \\
\hline 58 & 236.16 & 217.58 & $9.3 \%$ & $8.6 \%$ \\
\hline 59 & 265.81 & 247.53 & $10.6 \%$ & $9.9 \%$ \\
\hline 60 & 303.92 & 286.02 & $12.4 \%$ & $11.7 \%$ \\
\hline 61 & 354.70 & 337.31 & $14.6 \%$ & $13.9 \%$ \\
\hline 62 & 425.77 & 409.09 & $18.3 \%$ & $17.6 \%$ \\
\hline 63 & 532.33 & 516.70 & $25.7 \%$ & $24.9 \%$ \\
\hline 64 & 709.87 & 696.00 & $36.3 \%$ & $35.6 \%$ \\
\hline 65 & 1064.88 & 1054.49 & $91.5 \%$ & $90.6 \%$ \\
\hline
\end{tabular}


We also perform this calculation for the different scenarios which we examined in section 4.2.

\begin{tabular}{|l|c|c|c|c|}
\hline $\begin{array}{c}\text { Table 6: Monthly savings amount } \\
\text { needed to close the gap in nominal } \\
\text { terms }\end{array}$ & Age & $\begin{array}{c}\text { Number of } \\
\text { children }\end{array}$ & $\begin{array}{c}\text { Monthly } \\
\text { savings amount } \\
\text { needed } \\
(3 \%)\end{array}$ & $\begin{array}{c}\text { Monthly } \\
\text { savings amount } \\
\text { needed } \\
(5 \%)\end{array}$ \\
\hline Representative occupations & $(1)$ & $(2)$ & $(3)$ & $(4)$ \\
\hline Kindergarten teacher & 42 & no & 21.45 & 16.39 \\
\hline Insurance agent & 31 & no & -- & -- \\
\hline Sales person & 43 & yes & 47.91 & 37.06 \\
\hline Office clerk & 39 & no & 20.41 & 15.00 \\
\hline Female asset amplifiers & & & & \\
\hline Journalist & 32 & yes & 6.72 & 4.50 \\
\hline Municipal clerk & 42 & yes & -- & -- \\
\hline Consultant & 46 & yes & 129.82 & 104.23 \\
\hline Engineer & 28 & no & 0.90 & 0.57 \\
\hline Doctor & 38 & no & 20.49 & 14.87 \\
\hline
\end{tabular}

Table 6 shows the monthly savings amount needed for each of our scenarios to close the gender pension gap without adjusting for inflation. Female municipal clerks and insurance agents do not have to save extra amounts of money, since they face a negative gender pension gap. It would be their male counterparts who needed to save more.

As an example for a representative job, consider a female office clerk. With an interest rate of $3 \%$, a female office clerk age 39 with no kids needs to save an extra 20.41 Euro per month to close the gender pension gap upon retirement when living for another 15 years. Relative to her annual income, the female office clerk described above would have to save $1 \%$ more each year to close the gender pension gap.

Next, we turn to female asset amplifiers. With an interest rate of 3\%, a female doctor age 38 with no kids needs to save an extra 20.49 Euro per month to close the gender pension gap upon retirement when living for another 15 years. Relative to her annual income, the female doctor would only have to save $0.5 \%$ more each year to close the gender pension gap. 
If we assume an annual inflation rate of $1.5 \%$, we obtain the following results:

\begin{tabular}{|l|c|c|c|c|}
\hline $\begin{array}{c}\text { Table 7: Monthly savings amount } \\
\text { needed to close the gap in real terms }\end{array}$ & Age & $\begin{array}{c}\text { Number of } \\
\text { children }\end{array}$ & $\begin{array}{c}\text { Monthly } \\
\text { savings } \\
\text { amount } \\
\text { needed } \\
(3 \%)\end{array}$ & $\begin{array}{c}\text { Monthly } \\
\text { savings amount } \\
\text { needed } \\
(5 \%)\end{array}$ \\
\hline Representative occupations & $(1)$ & $(2)$ & $(3)$ & $(4)$ \\
\hline Kindergarten teacher & 42 & no & 30.67 & 23.43 \\
\hline Insurance agent & 31 & no & -- & - \\
\hline Sales person & 43 & yes & 68.49 & 52.98 \\
\hline Office clerk & 39 & no & 30.96 & 22.76 \\
\hline Female asset amplifiers & & & & \\
\hline Journalist & 32 & yes & 10.35 & 6.93 \\
\hline Municipal clerk & 42 & yes & -- & -- \\
\hline Consultant & 46 & yes & 177.48 & 142.48 \\
\hline Engineer & 28 & no & 1.38 & 0.87 \\
\hline Doctor & 38 & no & 31.56 & 22.90 \\
\hline
\end{tabular}

In this calculation, relative to her annual income, the female office clerk described above would have to save $1.5 \%$ more each year to close the gender pension gap. A female doctor with no child and aged 38 would have to save $0.8 \%$ more each year.

It is important to note that all calculations above assume that the gender pension gap remains the same over time for a given individual. For example, we assume that the female engineer aged 28 with no children faces a gender pension gap of $2.62 \%$ for her entire career. However, given our results on age cohorts, it is likely that the gender pay gap increases with age. Therefore, we think of our results as a lower bound and recommend that a woman should evaluate her individual gender pension gap every few years and adjust her savings accordingly. 


\section{$\underline{\text { References }}$}

Bajtelsmit, V.L., and VanDerhei, J.A. (1997), Risk aversion and retirement income adequacy. In: Positioning pensions for the twenty-first century. Michael S. Gordon, Olivia S. Mitchell, Marc M. Twinney, Eds. Philadelphia: University of Pennsylvania Press.

Bertrand, M. (2011): "New Perspectives on Gender," in Handbook of Labor Economics, ed. by David Card and Orley Ashenfelter. Elsevier, Amsterdam; London, Volume 4, Part B, pp. 1543-1590.

Bertrand, M. (2017): “The glass ceiling," Coase Lecture, London School of Economics, March 2017. Bundesministerium für Arbeit und Soziales (2016): Ergänzender Bericht der Bundesregierung zum Rentenversicherungsbericht 2016 gemäß § 154 Abs. 2 SGB VI (Alterssicherungsbericht 2016).

Chhaochharia, V., Ghosh, S., Niessen-Ruenzi, A., and Schneider, C. (2019): Child care and women's careers in firms, Working Paper.

Correll, S. J., Benard, S., and Paik, I. (2007). "Getting a Job: Is There a Motherhood Penalty? 1." American Journal of Sociology Vol., 112.5, pp. 1297-1339.

Flory, J. (2011): Then Gender Pension Gap. Entwicklung eines Indikators für faire Einkommensperspektiven von Frauen und Männern. Fraunhofer-Institut für Angewandte Informationstechnik (FIT), St. Augustin.

Jianakoplos, N., and Bernasek, A. (1998), Are women more risk averse?, Economic Inquiry, Vol. 36, pp. 620-630.

Sunden, A.E., and Surette, B.J. (1998), Gender Differences in the Allocation of Assets in Retirement Savings Plans, American Economic Review, Vol. 88, pp.207-211. 